\title{
Factors Affecting Women's Participation in Namibia's Workforce: Evidence from the 2009/10 Namibia Households Incomes and Expenditure Survey
}

\author{
Pempelani Mufune ${ }^{1}$ \\ ${ }^{1}$ Department of Sociology, University of Namibia, Namibia \\ Correspondence: Pempelani Mufune, Department of Sociology, University of Namibia, P/Bag 13301, Windhoek, \\ Namibia. E-mail: pmufune@unam.na
}

Received: June 13, 2013

Accepted: September 29, 2013

Online Published: October 15, 2013

doi:10.5539/ijbm.v8n22p40

URL: http://dx.doi.org/10.5539/ijbm.v8n22p40

\begin{abstract}
This study examines factors that influence the labour force participation of women in Namibia. The objectives are to (1) examine the rates of employment among women in Namibia; (2) compare patterns of employment and unemployment across women and men taking into account and type of work and industry; (3) gain insights into factors (marital status, age, residence, education) that promote or hinder women from work. The rationale is that identifying factors affecting women's participation in Namibia's workforcemay provide insight for practitioners and policy makers on how best to support women to either continue in employment or get engaged with work, thereby achieving Namibia's goal of gender equality. This study utilizes data from the Namibia Households Incomes and Expenditure Survey of 2009/2010. The results indicate Namibian women are increasingly entering the labour force as a result of post-independence policies that emphasize greater gender equality. Still women lag behind men in many aspects of labour force participation. Age, education level, and place of residence (urban residence) are predictors of labor force participation rates of women. Marital status seems to be more a predictor of men's than of women's paid employment. We conclude that increases in women's education in particular may prove useful in increasing women's employment in Namibia. Policies should target women's education.
\end{abstract}

Keywords: labour force participation, Namibia, employment, women, human capital variables

\section{Introduction}

There are slightly more women than men in Namibian society. According to the Namibia 2011 Population and Housing Census (National Statistical Agency [NSA], 2012) report there are 1,091,165 females compared to 1, 021,912 males in Namibia. Thus women constitute $51.6 \%$ of the population. Although Namibia has experienced an increase in the participation of women in the labour force since independence the various National Labour Force Surveys (NLFS) have all consistently shown that women are less likely to be in the labour force than males in Namibia. Thus the NLFS of 2000 showed that the labour force participation rate (LFPR) of women was $47.4 \%$ compared to $62.0 \%$ for men (Ministry of Labour, 2000). The LFPR for women was $36 \%$ compared to $59.6 \%$ for men in the NLFS of 2004 (Ministry of Labour, 2004) while the NLFS of 2008 showed that the LFPR of women was $49.9 \%$ compared to $61.6 \%$ for men (Ministry of Labour, 2008). The NLFS of 2012 shows that 63.2 per cent of women participate in the labour force compared to 69.1 per cent of men (NSA, 2012). Why should we be concerned with the labour force participation rates of women and men in Namibia? Significant literature from many parts of the world indicates that "unemployment is detrimental to wellbeing, as is evidenced through reduced financial resources and reduced ability to meet psychological needs such as meaningful activity and social contact" (Hogan, Kyaw-Mint, Harris \& Denronden, 2012 p 1). Research from other countries indicate that women earn less than men (Den Dulk \& De Ruijter, 2008; Hausmann, Tyson \& Zahidi, 2012), are more likely to work in the informal sector than in the formal sector (Klaveren, Tijdens, Hughie-Williams \& Martin, 2009) and are more likely to experience underemployment (Ollenburger, Grana \& Moore, 1989). In Namibia Ekström (1998) found differences in gross wages between males and females suggesting that females are discriminated against. However, public sector female workers suffered less discrimination than those in manufacturing and services. Similarly, the Gender Gap Index of the World Economic Forum that ranks countries according to how well women are doing in various countries found 
Namibia behind in several indices (Hausmann et al., 2012). In 2012 this Gender Gap Index ranked Namibia 41st of 135 countries. Namibia ranked 43rd on women's economic participation and opportunity, 31st on women's educational attainment, 106th on health and survival of women, and 49th on women's political empowerment (Hausmann et al., 2012). Except for its ranking on women's educational attainment this was Namibia's worst ranking since 2006, when its position was 38th.

The Namibian government has recognized the importance of reducing economic and employment inequalities between men and women. It has put legislation in place to ensure that women have access to the same employment opportunities as men. Such legislation also aims to provide similar benefits (i.e. promotion, job security, job satisfaction etc.) between men and women. In particular three pieces of legislation stand out: Labour Act of 2007, Affirmative Action (Employment) Act of 1998 and the Social Security Act (1994). Namibia's Labour Act of 2007 aims at 'regulating the conditions of employment of all employees in Namibia without discrimination on grounds of sex, race, colour, ethnic origin, religion, creed, or social or economic status, in particular ensuring equality of opportunity and terms of employment, maternity leave and job security for women' (Republic of Namibia, 2007). Namibia's Affirmative Action (Employment) Act of 1998 requires firms to set annual targets to achieve equal representation of the different groups of employees (including women) in management (Republic of Namibia, 1998). The Affirmative Action (Employment) Act 29 of 1998 aims to redress inequalities in employment and bring about equal opportunities in employment in accordance with Articles 10 and 23 of the constitution. It aims at achieving gender balance in decision-making and fostering fairness in recruitment, selection, appointment, training and promotion, and equitable remuneration for women (and for people with disabilities). The Act provides for the Employment Equity Commission (EEC) that oversees the design and implementation of the affirmative action plans. The Social Security Act provides some safeguards against loss of income due to sickness, pregnancy, injury and old age. It is financed by contributions from employers and employees. Participation is compulsory for employees and employers. Female employees can accrue maternity leave benefits equal to 80 per cent of their income, ranging from a minimum of N\$240 to a maximum of $\mathrm{N} \$ 2400$ per month.

The Labour Force Participation Rate is the proportion of the economically active population in a given population group, i.e. the number of economically active persons divided by the total population in the same population group (NSA, $2012 \mathrm{p} 41$ ). This study is concerned with finding out whether or not legislation put in place has assisted women to participate more equally in employment and the labour force. In particular it is concerned with examining the factors that influence the labour force participation of women in Namibia. The objectives are to (1) examine the rates of employment among women in Namibia; (2) compare patterns of employment and unemployment across women and men taking into account and type of work and industry; (3) gain an understanding of the factors (marital status, age, residence, education) that promote or hinder women from work. Identifying factors affecting women's participation in Namibia's workforce may provide insight for practitioners and policymakers on how best to support women to either continue in employment or get engaged with work, thereby achieving Namibia's goal of gender equality.

\subsection{Conceptual Framework}

An underlying conceptual issue concerns the nature of the processes by which women participate in the labour force.

According to Ollenburger, Grana and Moore (1989) two major explanations of women's work patterns have been employed; the human capital model and the structural model. This analysis is not meant to work out the relative importance of human capital model and the structural model, but it is important to keep them in mind when interpreting the results. Human Capital refers to the total sum of abilities (skills, qualifications, experience and so forth) that individuals acquire in the life cycle and that they can sell to employers. The human capital model looks at labour force participation in relation to individual skill levels and other salient individual differences. It argues that there are a number of individual predictors for women's labor force participation in both rural and non-rural communities. In particular proponents of the human capital model argue that income and education are important in women's labour force participation. Women with lower family incomes are generally forced to participate more in the labour market than other women. Similarly, more educated women are more likely to join the labor force. The labour supply of men and women has been growing in post-apartheid South Africa due to the "significant number of Africans of working age who had been catching up on previously missed education" now entering the labour force (Casale and Posel, 2002). The increase in female labour force participation rates in South Africa was fueled by improved levels of education (Van der Westhuizen, Goga \& Oosthuizen, 2007). Ntuli and Wittenberg (2013) also found that in South Africa education is associated with higher labour force participation among black women. Income was the most salient predictor of labor force 
participation for rural women with lower family income predicting higher female labourparticipation rates (Maret \& Chenoweth, 1979, Ollenburger, Grana \& Moore, 1989). This is especially the case where they are married (Maret \& Chenoweth 1979). Marriage and having children have also been found to predict the labor force participation of rural women (Ntuli \& Wittenberg, 2013; Buchmann, et al. 2010). There is a wealth of literature exploring the impact of parenthood on labour participation experiences and employment. Many studies (e.g., Buchmann et al. 2010; Craig \& Sawrikar 2009; Den Dulk \& De Ruijter 2008; Ransford et al. 2008) indicate that parenthood, especially becoming a mother, significantly impacts on labour force participation, on career paths and progression. It also has an impact on work-family balance issues and contributes to the tension between the two. The structural model places emphasis on availability of jobs, geographic labor markets and the traditional segmentation of labor markets that affect opportunities for women. In particular jobs, businesses and industries are more developed and available in urban than in rural communities. Hence people in urban areas have more access to labour markets and participate more in the labour force than people in rural areas. Similarly in Ollenberger et al's (1989) research, a large gap existed between rural and urban women's labor force participation rates. Although these rural-urban differences remained strong predictors of higher participation rates for urban women, rural women had begun seeking outside employment at an accelerated rate. In South Africa urban residence is associated with higher labour force participation among black women (Ntuli and Wittenberg, 2013). Ollenburger et al (1989) report a study by Pigott (1985) which found that the opportunity for female employment in rural communities was a direct result of the geographical and ecological factors associated with the development of community business and industry. Kilkenny and Huffman (2003) found that there was no significant statistical difference between the city and rural poor with respect to work. One legacy of apartheid in Namibia is that rural areas are far from where the jobs are in urban areas and this affects the labour force participation rates of women.With regard to geography it is argued that labor markets are often localized and women choose to work closer to home than commute long distances for jobs (Fernandez \& Su, 2004). Women in female-segregated jobs seem to work even closer to home than other women (Fernandez \& Su, 2004). The review by Fernandez and Su (2004) points out that geography of residence and geography of jobs may affect labor market participation both spatially and socially, through employers' recruiting practices or job-seekers' active search behaviors. Thus the geography of residence seems to restrict the movement of women and therefore their labour market participation. The spatial-mismatch hypothesis argues that the decentralization of employment combined with persistent residential segregation has resulted in increased distances between African American residential areas and regions of rapid job growth and has restricted their labor market opportunities (Wang, 2010, p 183). "Residential segregation reduces employment opportunities for poor minorities. Accordingly, "living in high-poverty neighbourhoods undermines workforce participation and labour market outcomes primarily due to the physical distance between the residence and potential jobs and the limited access to networks informing people about job opportunities" (Li, Campbell \& Fernandez, 2013 p 4). Likewise the spatial entrapment of women hypothesis argues that women's domestic responsibilities have restricted their spatial mobility in searching for jobs, which reinforces occupational sex segregation (Wang, 2010, p 183). Labour markets are segmented i.e. split into primary and secondary sectors and women may be overrepresented in secondary sectors. In segmented labor markets vulnerable groups including women show lower participation rates and, even when they do enter the labor market, earn less and advance more slowly in their careers (Pignatti, 2010). Among rural women, proximity to an urban area led to higher rates of labor market experience among rural women (Ollenburger et al, 1989; Maret \& Chenoweth, 1979).

It seems that both structural factors as well as individual factors play an important role in explaining women's labourforce participation and employment patterns (Ollenburger et al, 1989; Tickamyer \& Bokemeier, 1988).

\section{Methods}

This study utilizes data from the Namibia Households Incomes and Expenditure Survey (NHIES) of 2009/2010. This is actually the latest household survey in the country that is conducted nationally. It collects data on income, consumption and expenditure patterns of households. The NHIES uses a two stage design in which the first stage is based on the Probability Proportional to Size (PPS) selection procedure while the second stage is based on the random sampling procedure (i.e., systematic sampling).It is thus a representative household probability sample that is conducted every five years. Besides demographic characteristics, household composition, education and literacy, access to services, marital status, ownership of assets and housing the survey also asks about labor force behavior, annual consumption and income.

Analyses: the concern of this paper is with identifying the factors that influence the participation of women in Namibia's labour force. These data were analyzed utilizing SPSS for Windows 20.0 software. The analysis takes place in three steps; first is a description of employment outcomes of women and men in the Namibian labour 
market. Secondly, this description is extended to include an examination of education, age, residential status and other factors that affect employment outcomes. Cross tabulationwas used to assess the distribution of labour force participation and employment by socio-demographic characteristics (sex, educational level, age group, marital status) and residential status. In the cross-tabulation, statistical significances of the associations between the labour force participation and explanatory variables were evaluated with the chi-squared test. Lastly backward logistic regression is utilized to identify the factors that may distinctively contribute to employment outcomes for women, taking into account the associations that may exist between variables possibly contributing to the outcome. The logistic models were reported using adjusted odds ratios (OR) and their $95 \%$ confidence intervals (CI).

\section{Results}

Comparison of employment characteristics by gender: the labour force participation rate of females is lower than that of males in Namibia (Table 1). Thus whereas $68.1 \%$ of women are in the labour force almost $74 \%$ of males are. In Namibia labour force activities are divided into two: formal and informal. Informal economic activities refer to transactions sometimes involving cash, which lie outside regular employment. Such transactions definitely bypass policies, rules and regulations of government and its planning agencies. Formal economic activities are those sanctioned by government. Higher paying jobs are usually found in the formal sector. As can be seen in Table 1, $71.3 \%$ of employed males are in the formal sector whereas only $61.5 \%$ of employed women are in the formal sector. On the other hand $42.5 \%$ of employed women are in informal sector. The comparable figure for men is $28.2 \%$. Most countries do not classify subsistence farming activities as employment activity but Namibia does. About $23.2 \%$ of Namibian women compared to $14.3 \%$ of men are subsistence farmers.

Table 1. Labour force participation and type of employment HIES (2009/10)

\begin{tabular}{cccc}
\hline & Total \# (\%) & Female\# (\%) & Male\# (\%) \\
\hline Labour force participation & $918450(70.8)$ & $474406(68.1)$ & $444044(73.9)$ \\
- Unemployed as \% of labour force & $310447(33.8)$ & $182471(38.5)$ & $127976(28.8)$ \\
- Employed as \% of labour force & $608003(66.2)$ & $291935(61.5)$ & $316068(71.2)$ \\
Formal labour market as \% employed: & $392518(64.5)$ & $166870(57.1)$ & $225648(71.3)$ \\
- Government employee or state enterprise & & & \\
& $94222(15.5)$ & $48297(16.5)$ & $45925(14.5)$ \\
- As an employer & $4285(0.7)$ & $1045(0.4)$ & $3240(1.0)$ \\
- Private sector employee & $294011(48.4)$ & $117528(40.3)$ & $176483(55.8)$ \\
Informal labour market as \% employed & $213537(35.5)$ & $124284(42.5)$ & $89252(28.2)$ \\
- Self-employed or own account worker & $85154(14.0)$ & $47704(16.3)$ & $37450(11.8)$ \\
- Family worker -paid/unpaid & $15310(2.5)$ & $8714(3.0)$ & $6595(2.1)$ \\
- Subsistence farm activities & $113073(18.6)$ & $67866(23.2)$ & $45207(14.3)$ \\
Not stated & $1949(0.3)$ & $781(0.3)$ & $1168(0.4)$ \\
\hline
\end{tabular}

Table 2. Occupation type for 15-64 year olds who were in the labour force by gender (HIES 2009/10)

\begin{tabular}{llcc}
\hline Occupational type & all workers & Women\# (\%) & Men \# (\%) \\
\hline Legislators, senior officials \& managers & 21486 & $7831(36.4)$ & $13655(63.6)$ \\
Professionals & 43830 & $24036(54.8)$ & $19794(45.2)$ \\
Technicians \& associate professionals & 27578 & $13763(49.9)$ & $13815(50.1)$ \\
Clerks & 33921 & $24743(72.9)$ & $9178(27.1)$ \\
Service shops \& market sales workers & 84630 & $49686(58.7)$ & $34944(41.3)$ \\
Skilled agricultural \& fishery workers & 144663 & $76243(52.7)$ & $68420(47.3)$ \\
Craft trade workers & 64995 & $12989(20.0)$ & $52006(80.0)$ \\
Plant and machine operators and assemblers & 24744 & $1127(4.6)$ & $23617(95.4)$ \\
Elementary occupations & 153414 & $78923(51.4)$ & $74491(48.6)$ \\
Armed forces & 6806 & $1804(26.5)$ & $5002(73.5)$ \\
TOTAL & 606067 & $291145(48.0)$ & $314922(52.0)$ \\
\hline
\end{tabular}

Note: $\chi^{2}(\mathrm{~N}=606067)=56771.28, \mathrm{p}<.000$, *statistical significant difference by gender. 
Among people in the labour force the most common occupation, regardless of gender, is elementary occupations followed by Skilled agricultural \& fishery workers and Service shops \& market sales workers (Table 2). Very few women work as legislators, senior officials and managers. Thus only 36.4 per cent of the 21,419 people working in these occupations are women. The situation is more balanced among those working as professionals, technicians and associate professionals. Thus 54.8 per cent of professionals and 49.9 per cent of technicians and associate professionals in Namibia are women. This is not surprising as professionals and associate professionals include nurses and teachers. Women clearly dominate as clerks (72.9\%) and service shops and market sales workers $(58.7 \%)$. On the other hand, men dominate in crafts, plant and machine operators and assemblers, and the armed forces (Table 2). Chi-square values show that these differences between men and women are statistically significant.
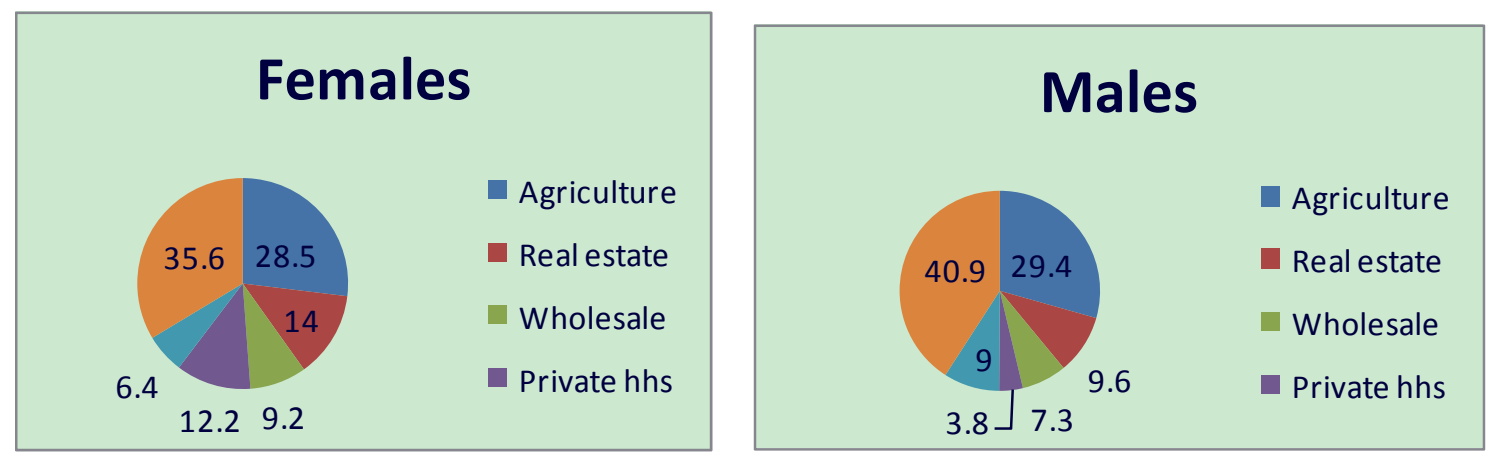

Figure 1. Employment by industry and gender, Namibia (NHIES 2009/10)

The proportion of women to total employees is shown in Figures 1 and Table 3. At 30 per cent, agriculture is the biggest employer, followed by real estate, renting and business activities (11.7\%); wholesale and retail trade, and repair of motor vehicles (8.2\%); and private households with employed persons (8\%). Table 3 and Figure 1 show that although most women are in these industries, they only dominate employment in health and social work (76.5\%); private households (74.4\%); education (62.4\%); hotels and restaurants $(59.8 \%)$; and financial intermediation (59.7\%). More women than men are also employed in real estate, renting and business activities (57.4\%) and wholesale and retail trade, and repair of motor vehicles $(53.8 \%)$.

These industries are considered as 'feminized' in Namibia. LaRRi (2004) found that 40 per cent of workers believe that women are concentrated in 'typical women's' jobs. Thus almost all domestic workers in private households are female. Most people employed in the health sector are nurses, who are overwhelmingly women. Similarly, most social workers are women. During colonial times these occupations were only open to women. Similarly, most people employed in the education sector are teachers. There are more women (60.6\%) teaching in Namibia than men (NANTU, 2009). Real estate, renting and business activities, and wholesale and retail trade mostly involve clerical and sales work and these are the occupations where most women are likely to get jobs. 
Table 3. Industry of employment for 15-64 year olds who were in the labour force by gender status (NHIES 2009/10)

\begin{tabular}{lccc}
\hline Sector & All workers\# (\%) & Women\# (\%) & Men\# (\%) \\
\hline Agriculture & $181772(30.0)$ & $85900(47.3)$ & $95872(52.7)$ \\
Fishing & $13312(2.2)$ & $4251(31.9)$ & $9061(68.1)$ \\
Mining \& quarrying & $9982(2.2)$ & $2043(20.5)$ & $7939(79.5)$ \\
Manufacturing & $29083(4.8)$ & $9816(33.8)$ & $19267(66.2)$ \\
Electricity, gas \& water & $3756(0.6)$ & $769(20.5)$ & $2987(79.5)$ \\
Construction & $32347(5.3)$ & $2984(9.3)$ & $29660(90.7)$ \\
Wholesale 7 retail trade, repair of & $49695(8.2)$ & $26759(53.8)$ & $22936(46.2)$ \\
motor vehicles & & $9698(59.8)$ & $8420(40.2)$ \\
Hotels \& restaurants & $16205(2.7)$ & $3131(16.8)$ & $15912(83.2)$ \\
Transport, storage \& communication & $18690(3.1)$ & $4802(59.7)$ & $3245(40.3)$ \\
Financial intermediation & $8047(1.3)$ & $40744(57.4)$ & $30291(42.6)$ \\
Real estate, renting \& business & $71035(11.7)$ & $18393(39.4)$ & $28269(60.6)$ \\
activities & & & $13516(37.6)$ \\
Public administration, defence\& & $46662(7.7)$ & $22388(62.4)$ & $3962(23.5)$ \\
social security & & $12866(76.5)$ & $10561(57.9)$ \\
Education & $35905(5.9)$ & $7666(42.1)$ & $12398(25.6)$ \\
Health \& social work & $16828(2.8)$ & $36077(74.4)$ & $1119(51.3)$ \\
Other community, social \& personal & $18227(3.0)$ & $1063(48.7)$ & $291147(48.0)$ \\
services & & & \\
Private households with employed & $48475(8.0)$ & & \\
persons & $2182(0.4)$ & & \\
Extra territorial organizations \& & $3864(1.7)$ & & \\
bodies & $608066(100.0)$ & & \\
Not recorded & & & \\
Total & & & \\
\hline
\end{tabular}

Note: $\chi 2(16, \mathrm{~N}=608066)=62826.49, \mathrm{p}<.000$, *statistical significant difference by gender.

\subsection{Effect of Education on Labour Force Participation}

The likelihood of woman being in a given occupation also varies with education. Thus among legislators, senior officials and managers, 87 per cent have secondary or tertiary education and among professionals 68 per cent have tertiary education. On the other hand, 74 per cent of skilled agricultural and fishery workers have primary education or less (Mufune, 2013). As shown in Table 4 there are more people with primary school and junior high secondary education unemployed than any other educational group. Although this applies to both women and men, women are more affected by lack of education than men.

Table 4. Employment status for female and male educational groups (\%)

\begin{tabular}{lllll}
\hline \multirow{2}{*}{ Educational level } & \multicolumn{3}{c}{ Females $^{1}$} & \multicolumn{2}{c}{ Males $^{2}$} \\
\cline { 2 - 5 } & Employed & Unemployed & Employed & Unemployed \\
\hline Primary school & $611152(86.6)$ & $9422(13.4)$ & $79354(91.1)$ & $7757(8.9)$ \\
Junior high school & $89530(88.6)$ & $11569(11.4)$ & $85460(92.4)$ & $7076(7.6)$ \\
Senior high school & $48058(91.4)$ & $4630(8.6)$ & $52677(93.4)$ & $3700(6.6)$ \\
University/technical undergraduate & $2091(97.9)$ & $44(2.1)$ & $1678(94.3)$ & $101(5.7)$ \\
University post graduate & $16038(96.3)$ & $624(3.7)$ & $18882(94.6)$ & $1076(5.4)$ \\
Post standard 10/grade 12 education & $855(81.7)$ & $192(18.3)$ & $2983(99.0)$ & $30(1.0)$ \\
Teachers training & $8796(88.6)$ & $1136(11.4)$ & $7070(90.5)$ & $739(9.5)$ \\
Total & $227719(89.2)$ & $27617(10.8)$ & $248083(92.4)$ & $20479(7.6)$ \\
\hline 1
\end{tabular}

${ }^{1} \chi^{2}(\mathrm{~N}=255336)=1886.21, \mathrm{p}<.000 ;{ }^{2} \chi^{2}(\mathrm{~N}=268562)=669.27, \mathrm{p}<.000$.

\subsection{Age and Labour Force Participation}

As shown in Table 5 labour force participation rates of women in Namibia differ according to age. Women aged 15-19 have a low labour participation rate of 30.5\%. LFPR are highest between 20-24 years and 45-49 years of 
age. They then progressively fall from 50-54 years of age onwards. The similar is the case for men, although the participation rates of men remain high up to age group 50-54. There are remarkable differences in the participation rates of men and women from age 40-44 to 65 years plus. Thus whereas among females aged $44-49,88 \%$ are in the labour force, $95 \%$ of men are. Similarly among women aged $45-49$ years $86.5 \%$ are in the labour force. The comparable figure for men is $94 \%$. Whereas among females aged $50-54,74 \%$ are in the labour force, $91 \%$ of men are. Among women aged 55-59, 60-64 and 65 plus years $60.3 \%, 34 \%$ and $16.5 \%$ respectively participate in the labour force. The comparative figures for men are $83.7 \%, 47.4 \%$ and $31.6 \%$. These figures indicate that older men participate in the labour force much more than older women. The likelihood of a woman being in employment also varies with age (not shown in table). Thus, according the NHIES 2009/10 data, 16 per cent of those aged 15-24 years are employed, while 32.6 per cent of those aged 25 - 34 years are employed. Among men the comparable figures are 17.2 per cent and 31.4 per cent.

Table 5. Labour force participation rates for femalesof different age groups

\begin{tabular}{llll}
\hline \multirow{2}{*}{ Age group } & \multicolumn{3}{c}{ Labour force participation rates } \\
\cline { 2 - 4 } & Total & Labour force & LFPR (\%) \\
\hline $15-19$ & 128,831 & 39,921 & 30.5 \\
$20-24$ & 108,224 & 89123 & 82.4 \\
$25-29$ & 89,582 & 83,069 & 92.7 \\
$30-34$ & 74,899 & 69,216 & 92.4 \\
$35-39$ & 59,482 & 54,284 & 91.3 \\
$40-44$ & 51,240 & 45,199 & 88.2 \\
$45-49$ & 42,182 & 36,493 & 86.5 \\
$50-54$ & 32,321 & 23,906 & 74.0 \\
$55-59$ & 25,720 & 15,509 & 60.3 \\
$60-64$ & 21,586 & 7,338 & 34.0 \\
65 plus & 62,686 & 10,348 & 16.5 \\
TOTAL & 696,753 & 474,406 & 68.1 \\
\hline
\end{tabular}

\subsection{Residence and Labour Force Participation}

There are considerable differences in urban and rural areas. The rates for females and males in urban areas are $75.7 \%$ and $81 \%$ respectively. The corresponding rates for rural areas are $63 \%$ and $68 \%$ respectively. The likelihood of a woman being in employment also varies with residence (not shown in table). Thus whereas $49.4 \%$ of urban women are employed, $36.8 \%$ of rural women are. The comparable figures for men are $61.1 \%$ and $46.1 \%$.

\subsection{Marital Status and Labour Force Participation}

Among those that are in some kind of union-married with certificate, married traditionally and consensual union-there seem to be substantial differences in the unemployment rates of men and women. Men seem to have substantially higher employment rates than women in these groups (Table 6). The greatest differences are between men and women that are in consensual union 17 percentage points), married traditionally (15 percentage points) and married with certificate (13 percentage points). The differences in employment between men and women that are widowed, divorced or separated and never married seem to be small. 
Table 6. Marital status and labour force participation

\begin{tabular}{|c|c|c|c|}
\hline Marital status & Employed & Unemployed & Percent employed \\
\hline \multicolumn{4}{|c|}{ Married with certificate } \\
\hline Female & 66740 & 19457 & 77.4 \\
\hline Male & 79360 & 8261 & 90.5 \\
\hline \multicolumn{4}{|c|}{ Married traditionally } \\
\hline Female & 35150 & 12832 & 73.2 \\
\hline Male & 42536 & 5562 & 88.4 \\
\hline \multicolumn{4}{|c|}{ Consensual union } \\
\hline Female & 28368 & 24185 & 53.9 \\
\hline Male & 24185 & 9737 & 71.2 \\
\hline \multicolumn{4}{|l|}{ Widowed } \\
\hline Female & 18140 & 3841 & 82.5 \\
\hline Male & 3199 & 411 & 88.6 \\
\hline \multicolumn{4}{|c|}{ Divorced/separated } \\
\hline Female & 13575 & 4541 & 74.9 \\
\hline Male & 2480 & 759 & 76.5 \\
\hline \multicolumn{4}{|l|}{ Never married } \\
\hline Female & 134420 & 123754 & 52.0 \\
\hline Male & 145144 & 107571 & 57.4 \\
\hline \multicolumn{4}{|l|}{ Don't know } \\
\hline Female & 89 & 0 & 100 \\
\hline Male & 47 & 30 & 61 \\
\hline
\end{tabular}

\subsection{Factors Contributing to Labour Force Participation of Namibian Women}

The two models presented in Table 7 include the predictors-age, education, area of residence, and marital status. Model 1 includes females only while model 2 is for males. Model 1 is significant $\left(\chi^{2}=p \leq 0.00\right)$. Model 2 is also significant.

Table 7. Factors influencing women's employment adjusted for age, marital status, education and residence

\begin{tabular}{lcc} 
& \multicolumn{1}{c}{ Model 1} & \multicolumn{1}{c}{ Model 2} \\
\cline { 2 - 3 } Age & \multicolumn{1}{c}{ Females -Odds ratio $(95 \% \mathrm{CI})$} & Males Odds ratio $(95 \% \mathrm{CI})$ \\
Education & $0.79[0.922-0.926]^{* *}$ & $0.63[0.93-0.94]^{* *}$ \\
Primary & & \\
Secondary & $0.55[0.54-0.60]^{* *}$ & $0.21[0.77-0.83]^{* *}$ \\
Tertiary & $0.41[0.63-0.69]^{* *}$ & $0.15[1.12-1.22]$ \\
Residential status & $1.2[0.28-0.31]^{* *}$ & $0.58[0.53-0.58]$ \\
Rural & & \\
Urban & $0.43[0.63-0.69]^{* *}$ & $0.50[0.59-0.60]^{* *}$ \\
Marital status & & \\
Married with certificate & & \\
Married Traditionally/customary & $22.0[0.00-0.00]$ & $0.81[0.55-1.25]$ \\
Consensual union & $21.4[0.00-0.00]$ & $0.64[0.35-0.78]^{*}$ \\
Widowed & $22.0[0.00-0.00]$ & $0.87[0.27-0.62]^{* *}$ \\
Divorced or separated & $23.1[0.00-0.00]$ & $0.95[1.72-3.90]^{* *}$ \\
Never married & $21.9[0.00-0.00]$ & $1.43[0.76-1.73]$ \\
\hline
\end{tabular}

${ }^{* *} \mathrm{p}<.001,{ }^{* \mathrm{p}}<.001$.

For women the significant variables for predicting employment are age (OR $=0.79,95 \% \mathrm{CI}=0.922-0.926, \mathrm{p}$ $\leq 0.00)$ and residence $(\mathrm{OR}=0.43,95 \% \mathrm{CI}=0.63-0.69, \mathrm{p} \leq 0.00)$. Education is also an important predictor of employment for women (primary OR $=0.55,95 \% \mathrm{CI}=0.54-0.60, \mathrm{p} \leq 0.00$. Secondary $\mathrm{OR}=0.41,95 \% \mathrm{CI}=$ $0.63-0.69, \mathrm{p} \leq 0.00$. Tertiary $\mathrm{OR}=1.2,95 \% \mathrm{CI}=0.28-0.31, \mathrm{p} \leq 0.00$ ). Marital status does not predict women's employment. For men secondary and tertiary education are not predictors of employment. On the other 
hand marital status is an important predictor of employment for men (married traditionally/ customary OR = $0.64,95 \% \mathrm{CI}=0.35-0.78, \mathrm{p} \leq 0.00$. Consensual union $\mathrm{OR}=0.87,95 \% \mathrm{CI}=0.27-0.62, \mathrm{p} \leq 0.00$. Widowed $\mathrm{OR}=0.95,95 \% \mathrm{CI}=1.72-3.90, \mathrm{p} \leq 0.00$. Never married $\mathrm{OR}=0.9595 \% \mathrm{CI}=1.72-3.88, \mathrm{p} \leq 0.00$ ). Divorce and/or separation in men do not predict employment.

\section{Discussion}

Namibian women are increasingly entering the labour force as a result of post-independence policies that emphasize greater gender equality. In this paper we employed human capital model (as against the structural model) that looks at labour force participation in relation to individual skill levels and other salient individual differences and how they predict the labourforce participation of given groups. In particular we examined change in the labourforce participation of Namibian women using the human capital model that suggests paid jobs are distributed according to individual characteristics such as age, marital status, education level, and place of residence (whether rural or urban). Our results indicate that age, education level, and place of residence (urban residence) affect labor force participation rates of women. Marital status seems to be more a predictor of men's than of women's paid employment. Still women lag behind men in many aspects of labour force participation. Increases in women's education in particular may prove useful in increasing women's employment in Namibia. This is in line with other studies in Africa (Ntuli \& Wittenberg, 2013; Casale \& Posel, 2002; Van der Westhuizen et al, 2007) that show education is associated with higher labour force participation among women.

\section{References}

Buchmann, M. C., Kriesi, I., \& Sacchi, S. (2010). Labour market structures and women's employment levels. Work, Employment and Society, 24(2), 279-299. http://dx.doi.org/10.1177/0950017010362142

Casale, D., \& Posel, D. (2002). The Continued Feminisation of the Labour Force in SouthAfrica: An Analysis of Recent Data and Trends. South African Journal of Economics, 70(1), 156-184. http://dx.doi.org/10.1111/j.1813-6982.2002.tb00042.x

Craig, L., \& Sawrikar, P. (2009). Work and family: How does the (gender) balance change as children grow? Gender, Work and Organization, 16(6), 684-709.

Den Dulk, L., \& De Ruijter, J. (2008). Managing work-life policies: disruption versus dependency arguments. Explaining managerial attitudes towards employee utilization of work-life policies. International Journal of Human Resource Management, 19(7), 1222-1236.

Fernandez, R. M., \& Su, C. (2004). Space in the study of labor markets. Annual Review of Sociology. http://dx.doi.org/10.1146/annurev.soc.29.010202.100034

Hausmann, R., Tyson, L., \& Zahidi, S. (2012). The Global Gender Gap Report 2012. Geneva: World Economic Forum.

Kilkenny, M., \& Sonya, K. H. (2003). Rural/urban welfare program and labor force participation. American Journal of Agricultural Economics, 85, 914-27. http://dx.doi.org/10.1111/1467-8276.00497

Klaveren, M., Tijdens, K., Hughie-Williams, M., \& Martin, N. (2009). An Overview of Women's Work and Employment in Botswana Decisions for Life MDG3 Project Country Report No. 5. University of Amsterdam

LaRRI. (2004). The Namibian Labour Market-Workers experiences and perceptions LaRRi Windhoek.

Li, H., Campbell, H., \& Fernandez, S. (2013). Residential Segregation, Spatial Mismatch and Economic Growth across US Metropolitan Areas. Urban Studies, 50(13), 2642-2660.

Maret, E., \& Chenoweth, L. (1979). The Labor Force Patterns of Mature Rural Women. Rural Sociology, 44(4), 736-753.

Ministry of Labour. (1997, 2000, 2004, 2008). The Namibia Labour Force Survey. Ministry of Labour Windhoek.

Mufune, P. (2013). Female Employment and Unemployment in Namibia. Small States Digest, 1, 14-28.

Namibia National Teachers Union (NANTU). (2009). NANTU Gender Policy. NANTU Windhoek.

National Statistical Agency. (2012). The Namibia Labour Force Survey. NSA, Windhoek.

Ntuli, M and Wittenberg. (2013). Determinants of Black Women's Labour Force Participation in Post-Apartheid. South Africa Journal of African Economies, 22(3), 1-28. 
Ollenburger, J. C., Grana, S. J., \& Moore, H. A. (1989). Labor force participation of rural farm, nonfarm, and urban women: A panel update. Rural Sociology, 54(4), 533-550.

Pignatti, N. (2010). Labor Market Segmentation and the Gender Wage Gap in Ukraine ESCIRRU Working Paper $\quad$ No. $17 . \quad$ Retrieved from http://www.diw.de/documents/publikationen/73/diw_01.c.347727.de/diw_escirru0017.pdf

Ransford, C. R., Crouter, A. C., \& McHale, S. M. (2008). Implications of work pressure and supervisor support for fathers', mothers' and adolescents' relationships and well-being in dual-earner families. Community, Work and Family, 11(1), 37-60. http://dx.doi.org/10.1080/13668800701785312

Republic of Namibia. (1994). Social Security Act, 1994. Article 56 of that Constitution. No. 34 of 1994: Government gazette Windhoek.

Republic of Namibia. (2007). Labour Act No. 11 of 2007 Government gazette Windhoek.

Republic of Namibia. (2008). Affirmative Action (Employment) Act No. 29 of 2007 Government gazette Windhoek.

Tickamyer, A., \& Janet, B. (1988). Sex differences in labor market experiences. Rural Sociology, 53(2), 165-89.

Van der Westhuizen, C., Goga, S., \& Oosthuizen, M. (2007). Women in the South African labour market: 1995-2005. DPRU Working Paper 07/118. Cape Town: Development Policy Research Unit.

Venter, K. (n.d.). Fathers 'Care' Too: The Impact of Family Relationships on the Experience of Work for Parents of Disabled Children. Sociological Research Online, 16(3), 1.

Wang, G. (2010). How does geography matter in the ethnic labor market segmentation process? A case study of Chinese immigrants in the San Francisco CMSA. Annals of the Association of American Geographers, 100, 182-201. http://dx.doi.org/10.1080/00045600903379083

\section{Copyrights}

Copyright for this article is retained by the author(s), with first publication rights granted to the journal.

This is an open-access article distributed under the terms and conditions of the Creative Commons Attribution license (http://creativecommons.org/licenses/by/3.0/). 